\title{
Jörg Feuchter
}

\section{The Middle Ages in the Genetics Lab}

\begin{abstract}
In the twenty-first century the medieval ended up in a place where - only a few decades ago - no one would have expected to find it: the genetics lab. Today, highly specialized state-of-the-art research institutes are busy analysing medieval DNA samples. The objects they scrutinize represent the entire Middle Ages. Sometimes the scientific objective of the analysis resides primarily in the realm of history/archaeology; sometimes the questions asked are of a biological nature. A rapidly growing field of more or less intertwined genetic, historical, and archaeological knowledge production is developing, and the medieval has become relevant to genetics, as well as the other way around. Given the breath-taking pace of research, it is virtually impossible to keep track of all pertinent developments. This paper demonstrates the relevance of the medieval for genetics in several contexts: medieval pandemics constitute a source of important data for today's medical research; medieval migrations are both showcases and test cases for the tools of population genetics, and the medieval millennium (500-1500 AD) might well become an essential period for studies in recent human evolution. Even such much-studied medieval objects as parchments have the potential to reveal a whole field of previously hidden data by providing polyvalent source material. Yet real interdisciplinary cooperation between geneticists and medievalists remains rare. There is an urgent need for more critical engagement, which should hopefully also provide us with more complete overviews of the growing field of which the present contribution is only intended to give some initial insights.
\end{abstract}

Keywords: ancient DNA, archaeology, genetics, migrations, evolution, pandemics, parchment

\section{Introduction}

In the twenty-first century, the medieval ended up in a place where - only a few decades ago - no one would have expected to find it: the genetics lab. Today, highly specialized state-of-the-art research institutes ${ }^{1}$ are busy analysing medieval DNA samples. The objects they scrutinize represent the entire Middle Ages, ranging from

\footnotetext{
1 For an overview of the facilities see Ann GibBons, Ancient DNA Divide, in: Science 352, 6292 (2016), pp. 1384-1387. On one of the most prominent and prolific ones among them, the Max-Planck-Institute for the Science of Human History in Jena (Germany), see Jörg FEUCHTER, Die DNA der Geschichte, in: Frankfurter Allgemeine Zeitung, 05 November 2014, p. N4, online: http://www.faz.net/aktuell/feuille
}

\footnotetext{
Jörg Feuchter, Berlin-Brandenburg Academy of Sciences and Humanities, Regesta Imperii Regesten Kaiser Friedrichs III., Jägerstr. 22-23, 10117 Berlin, Germany, feuchter@bbaw.de 
burial sites which were occupied during the so-called 'barbarian invasions' (that is, the period marking the beginning of the Middle Ages), to late-medieval plague cemeteries. Scientists even feed charters written on parchment, the epitome of the traditional object medievalists study, into their sequencing machines. Sometimes the scientific objective of the analysis resides primarily in the realm of history/archaeology; sometimes the questions asked are of a biological nature. A rapidly growing field of more or less intertwined genetic, historical, and archaeological knowledge production is developing, and the medieval has become relevant to genetics, as well as the other way around. Given the breath-taking pace of research, it is virtually impossible to keep track of all pertinent developments and the task becomes even more difficult as historians of the Middle Ages and geneticists are only just beginning to talk to each other. Real interdisciplinary cooperation remains rare. There is an urgent need for more critical engagement, ${ }^{2}$ which should hopefully also provide us with more complete overviews of the growing field of which the present contribution is only intended to give some initial insights.

The research areas which I have chosen to highlight are connected with the following phenomena: 1) pandemics, 2) migrations, 3) recent human evolution, and 4) parchment. Each of these areas will be outlined only very briefly. In addition, I want to make clear from the very outset that my own perspective is, throughout, that of a scholar who is trained and who works in the field of medieval history, not in biology. This disciplinary background inevitably limits my understanding of geneticists' research methods and purposes and, as a consequence, my own view of the intersection between genetics and Medieval Studies is necessarily conditioned by my disciplinary perspective.

\section{Pandemics}

The so-called 'Black Death' of the mid-fourteenth century took the lives of large swathes of the European population ${ }^{3}$ and was connected to a huge wave of antiJewish pogroms and displays of public penance, such as the flagellant

ton/geisteswissenschaften/neues-max-planck-institut-zur-dna-in-der-geschichte-13246120.html (last accessed 15/05/2019).

2 This case is made by Stefanie SAmida / Jörg Feuchter, Why Archaeologists, Historians and Geneticists Should Work Together - and How, in: The Genetic Challenge to Medieval History and Archaeology $=$ Medieval Worlds 4 (2016), pp. 5-21, and by ID., Für einen kritischen Dialog zwischen Geschichtswissenschaft und Genetic History, in: NTM Zeitschrift für Geschichte der Wissenschaften, Technik und Medizin 26(3) (2018), pp. 34-40.

3 For a recent critical overview of Black Death mortality estimates see Joris Roosen / Daniel R. CURTIS, The 'Light Touch' of the Black Death in the Southern Netherlands: An Urban Trick?, in: The Economic History Review 71 (2018), pp. 1-25, esp. pp. 1-2. 
movement. ${ }^{4}$ It is also one of the fields of research in which it hardly comes as a surprise that genetics and Medieval Studies intersect: genetics is, after all, closely connected to medical studies and the plague represents one of the greatest and most devastating pandemics in history. And indeed, during the past years, geneticists have made huge steps forward in establishing knowledge not only about the late medieval pandemic, but also about the recurrent appearances of the plague in all periods of history. A notable example is the so-called Justinian Plague, the early medieval precursor of the fourteenth-century Black Death. In addition, not only have the early modern outbreaks of the disease been analysed but there are also projects which delve even further back in time in order to find occurrences of plague bacteria in much earlier periods. ${ }^{5}$

As new research and its insights continue to be published, the following remarks will be limited to a very general overview of some pandemics from the perspective of our question regarding the relevance of the medieval. First of all, it should be underlined that recent genetic research has removed any doubt that the Black Death really was the plague, i. e. that the pandemic was caused by the pathogen that is known as yersinia pestis. The key breakthrough in solving this particular problem was furnished by a study based on DNA taken from human remains in a London cemetery, which successfully led to the reconstruction of the full genome of the medieval plague bacterium. ${ }^{6}$ In follow-up studies, the pathogen's phylogeny has been traced in more detail, both for later and for earlier periods. ${ }^{7}$

\footnotetext{
4 See the classic monograph František GraUS, Pest - Geissler - Judenmorde. Das 14. Jahrhundert als Krisenzeit (Veröffentlichungen des Max-Planck-Institutes für Geschichte 86), Göttingen 1987.

5 Simon RASmuSSEN et al., Early Divergent Strains of Yersinia Pestis in Eurasia 5,000 Years Ago, in: Cell 163(3) (2015), pp. 571-582.

6 Kirsten I. Bos / Verena J. Schuenemann / Geoffrey Brian Golding / Hernán A. BuRBano / Nicholas WAGLeCHNer / Brian K. Coombes / Joseph B. MCPheE / Sharon N. DeWitte / Matthias MeYeR / Sarah SCHMEDES / James W. Wood / David J. D. EARN / Donald HERRING / Peter BAUER / Hendrik N. PoinaR / Johannes KRAUSE, A Draft Genome of Yersinia Pestis from Victims of the Black Death, in: Nature 478, 7370 (2011), pp. 506-510; Kirsten I. Bos / Philip Stevens / Kay Nieselt / Hendrik N. PoinaR / Sharon N. DEWITTE / Johannes KRAUSE, Yersinia Pestis: New Evidence for an Old Infection, in: PLoS One 7(11) (2012), e49803.
}

7 See Maria A. Spyrou / Rezeda I. Tukhbatova / Michel Feldman / Joanna Drath / Sacha Kacki / Julia Beltrán de HeRedia / Susanne ARnold / Airat G. Sitdikov / Dominique CAStex / Joachim WaHL / Ilgizar R. GazimzYanov / Danis K. NuRgaliev / Alexander Herbig / Kirsten I. Bos / Johannes KRAUSE, Historical Y. Pestis Genomes Reveal the European Black Death as the Source of Ancient and Modern Plague Pandemics, in: Cell Host Microbe 19(6) (2016), pp. 874-881; Michal Feldman / Michaela HARBECK / Marcel Keller / Maria A. SPYRou / Andreas RotT / Bernd TRAutmann / Holger Christian Scholz / Bernd Päffgen / Joris Peters / Michael McCormick / Kirsten I. Bos / Alexander Herbig / Johannes Krause, A High-Coverage Yersinia Pestis Genome from a Sixth-Century Justinianic Plague Victim, in: Molecular Biology and Evolution 33(11) (2016), pp. 2911-2923; Kirsten I. Bos / Alexander Herbig / Jason W. SAHL / Nicholas WAGlechner / Mathieu Fourment / Stephen A. Forrest / Jennifer Klunk / Verena J. Schuenemann / Debi Poinar / Melanie Kuch / G. Brian Golding / Olivier J. Dutour / Paul S. Keim / David M. WAGner / Edward C. Holmes / Johannes 
In spite of first appearances, it has to be stressed that this research is not only of historic relevance, that is, it provides us with insights that are far broader than simply an improved understanding of the situation in the Middle Ages. ${ }^{8}$ Given the persistence of the plague bacteria today and the similitude of the medieval pathogen to its modern descendant, the analysis of the disease's earlier history is of some interest to pandemic research today. As Monica H. GREEN, a leading historian in the study of medieval pandemics, has put it: "The medieval Black Death, therefore, is far more than a mere historical curiosity; it is, in all its complexity, the source of vital data that can help us to establish scenarios for pandemic disease now and in the future." ${ }^{9}$ With GREEN, we can also conclude more generally that genetics is "A New Player in Disease History": ${ }^{10}$ genetic research has also provided new insight into further diseases that have proven to be persistent since (at least) medieval times, e. g. leprosy, although the state of our knowledge seems to be less advanced in these cases. ${ }^{11}$ A further example would be tuberculosis, yet another old scourge of humanity that still remains a threat even today. Geneticists have recently established that some strains of TB bacteria had reached the American continent long before the European conquerors arrived. The strain that made landfall in pre-Columbian America was, as has been demonstrated, transmitted by seals crossing the Atlantic from Africa to South America in, at

Krause / Hendrik N. PoInAR, Eighteenth Century Yersinia Pestis Genomes Reveal the Long-term Persistence of an Historical Plague Focus, in: Elife (2016), 5:e12994. For an earlier perspective from a historian who formulates research problems that concern the early medieval plague see Michael McCoRmick, Toward a Molecular History of the Justinianic Pandemic, in: Lester Knox LiTTLE (ed.), Plague and the End of Antiquity. The Pandemic of 541-750, Cambridge 2007, pp. 290-312.

8 This is, of course, not only true for the Middle Ages: quite recently the importance of connections between late medieval climate change, the history of the plague (on the basis of new genetic evidence), and the rise of Europe in the modern period have been stressed by Bruce CAMPBELL, The Great Transition. Climate, Disease and Society in the Late-Medieval World, Cambridge et al. 2016. For a critique, notably of Campbell's conclusions from genetic research, see Monica H. GREEN, Black as Death, in: Inference. International Review of Science 4(1) (2008), online https://inferencereview.com/article/black-as-death (last accessed 15/05/2019)

9 Monica H. GreEn, Editor's Introduction, in: ID. (ed.), Pandemic Disease in the Medieval World. Rethinking the Black Death (The Medieval Globe 1/2014), pp. 9-26, here p. 20.

10 ID., Genetics as a Historicist Discipline. A New Player in Disease History, in: Perspectives on History. The Newsmagazine of the American Historical Association (December 2014), pp. 30-31, online: www.historians.org/publications-and-directories/perspectives-on-history/december-2014/ge netics-as-a-historicist-discipline (last accessed 15/05/2019).

11 Tom A. Mendum / Verena J. Schuenemann / Simon Roffey / G. Michael TaYlor / Huihai Wu / Pushpendra Singh / Katie TucKer / Jason Hinds / Stewart T. Cole / Andrzej M. KiERzEK / Kay NiESElt / Johannes KRAUSE / Graham R. STEWART, Mycobacterium Leprae Genomes from a British Medieval Leprosy Hospital: Towards Understanding an Ancient Epidemic, in: BioMed Central Genomics 15 (2014), p. 270; Helen D. Donoghue et al., A Migration-driven Model for the Historical Spread of Leprosy in Medieval Eastern and Central Europe, in: Infection, Genetics and Evolution 31 (2015), pp. 250-256. 
the latest, the early medieval period. ${ }^{12}$ Recently, a research project dedicated to finding out about pathogen exchange between "New and Old World peoples" before and after 1492 has been funded by the European Research Council. ${ }^{13}$ Moreover, connections have been drawn between the distribution of some distinctive strains of TB and the Mongol expansion to the West in the thirteenth century. ${ }^{14}$ In fact, many studies of historical pandemics touch upon the issue of human migration, which will be treated in the following paragraph. At this point, however, we can summarize that 'the medieval' is particularly relevant to genetic pandemic research in two distinct contexts: a) in research concerning the earlier development of current pathogens and b) in research about ways of global transmission.

\section{Human Migration}

While pandemics already constitute a core subject at the intersection of genetics and medieval history, migrations possibly play an even more central role. And again, this does not come as a surprise. Firstly, the concept of 'migration' counts among the essential ideas of Population Genetics. Next to 'mutation', 'recombination', 'selection', and 'drift', it occupies an important place among the key elements which determine the general evolutionary processes that influence the genetic diversity of human - amongst other - populations. ${ }^{15}$ Secondly, the idea that DNA research could contribute substantially to the reconstruction of the history of human migrations became evident quite early on: already in 1987 the

12 Kirsten I. Bos et al., Pre-Columbian Mycobacterial Genomes Reveal Seals as a Source of New World Human Tuberculosis, in: Nature 514, 7523 (2014), pp. 494-497. For a general and accessible overview of historical plague and leprosy research in genetics see Anne GiBBons, On the Trail of Ancient Killers, in: Science 340, 6138 (2013), pp. 1278-1282.

13 “Communicable Disease Exchange in the Age of Seafaring”, online: http://www.shh.mpg.de/ 1019351/bos-warinner-erc-starting-grants (last accessed 15/05/2019). The principal investigator is Dr. Kirsten I. Bos, group leader at the Max-Planck-Institute for the Science of Human History in Jena (Germany).

14 Guislaine REFRÉGIER / Edgar AbAdÍA / Tomoshige MATSUmoto / Hiromi Ano / Tetsuya TAKASHIMA / Izuo Tsuyuguchi / Elif AKTAŞ / Füsun Beğendik Cömert / Michel Kiréopori Gomgnimbou / Stefan Panaiotov / Jody Phelan / Francesc Coll / Ruth Mc Nerney / Arnab Pain / Taane G. Clark / Christophe SolA, Turkish and Japanese Mycobacterium Tuberculosis Sublineages Share a Remote Common Ancestor, in: Infection, Genetics and Evolution 45 (November 2016), pp. 461-473, and, more recently, Igor Mokrousov / Egor A. SHITIKov / Yuriy A. SkIBA / Sergey KolChENKo / Ekaterina N. ChERNYAEVA / Anna A. VYAZOVAYA, Emerging Peak on the Phylogeographic Landscape of Mycobacterium Tuberculosis in West Asia: Definitely Smoke, Likely Fire, in: Molecular Phylogenetics and Evolution 116 (2017), pp. 202-212.

15 See Mark A. Jobling / Mattthew E. Hurles / Chris Tyler-Smith, Human Evolutionary Genetics. Origins, Peoples \& Disease, New York, Abingdon 2004, pp. 141-143. 
'Out-of-Africa' (II) or 'Recent African Origin' hypothesis - i. e. the idea that the anatomically modern human, which ultimately spread all around the world, came from a single African region of origin - was strongly supported by findings from population genetics. ${ }^{16}$ In order to understand why (apart from Prehistory) the Middle Ages are the one period most intensively scrutinized by geneticists interested in past human migrations, we have to take a closer look.

One reason why the Middle Ages are so attractive to some geneticists has to do with the general history of migrations, or rather modern assumptions about them. Many geneticists consider the medieval period to represent the last 'pristine' era before the early modern - post-1492 - colonization movements, which thoroughly mixed up the 'original' population compositions on a word-wide scale for the first time. As a consequence, pertinent data concerning the Middle Ages tend to be used as an indicative baseline that can indicate everything that had happened during the process of the dispersal of modern humans around the world. In other words: medieval populations are valuable for geneticists, since (as they claim is the case) they can be used as a model for the entire time since the global dispersal of anatomically modern humans. ${ }^{17}$ The validity of these assumptions cannot in fact be taken for granted at all.

Another reason why geneticists are particularly interested in medieval migrations consists in the relative scarcity of written sources in this period, at least during the Early and High Middle Ages. Results from genetic analyses thus seem to offer a much sought-after alternative approach that might help to answer difficult questions which are perceived to deserve modern science's attention: the Middle Ages doubtless play an essential and continuing role in contemporary modern discourses about historical identities. ${ }^{18}$ In other words, by 'solving' medieval mysteries, scientists demonstrate the power and capability of genetic approaches while guaranteeing public interest in their research and its results by linking both to the 'fashionable' Middle Ages.

There are also much more practical reasons for the interest of geneticists in the Middle Ages. One of the most obvious is that the ritual of earth burial was more

16 Rebecca L. Cann / Mark Stoneking / Allan C. WiLSON, Mitochondrial DNA and Human Evolution, in: Nature 325, 6099 (1987), pp. 31-36; Chris B. StRInGER / Peter ANDREWS, Genetic and Fossil Evidence for the Origin of Modern Humans, in: Science 239, 4845 (1988), pp. 1263-1268. See also Marianne Sommer, History in the Gene. Negotiations Between Molecular and Organismal Anthropology, in: Journal of the History of Biology 41(3) (2008), pp. 473-528, here pp. 510-511.

17 This assumption is particularly explicit, for example, in a highly controversial study mixing Molecular Anthropology with Economic Macroanalysis and (Animal) Behavioral Science: Quamrul ASHRAF / Oded GALOR, The 'Out of Africa' Hypothesis, Human Genetic Diversity, and Comparative Economic Development, in: American Economic Review 103 (February 2013), pp. 1-46.

18 Patrick J. GEARY, The Myth of Nations. The Medieval Origins of Europe, Princeton 2002. See also Jörg FEuChTER, Mittelalterliche Migrationen als Gegenstand der "Genetic History", in: Felix Wiedemann / Kerstin Hofmann / Hans-Joachim GeHRKe (eds.), Vom Wandern der Völker. Migrationserzählungen in den Altertumswissenschaften (Berlin Studies of the Ancient World 41), Berlin 2017, pp. 347-370, here pp. 354-55. 
widespread in this period than in Antiquity, when cremation was more widely practiced. As a consequence, a high number of medieval skeletal remains can still be found and - thanks to the revolutionary progress made in the analysis of ancient DNA (aDNA) in recent years - the genetic information contained in those bones is becoming increasingly easy to access. Until quite recently, geneticists and their research had to focus on DNA from living people. Any reconstruction of the situation in earlier periods thus inevitably remained hypothetical since it had to rely on the interpretation of recent genetic material and the assumption of continuity between modern populations and medieval ones. In recent years, however, the possibilities for sampling aDNA have improved breathtakingly: today, they make it possible to work on the original remains of medieval individuals. ${ }^{19}$

Although the quantity of studies from genetic history that touch on the question of medieval migrations has become quite impressive, more general surveys are not yet available. ${ }^{20}$ Nevertheless, we can tentatively identify two geographical foci of interest in this research: one of them is north-western Europe, including the North Atlantic, the other is the Western Mediterranean. Research concerning the former region mostly focusses on the Germanic migrations to the British Isles (Vikings from Scandinavia $^{21}$ and Anglo Saxons from the continental coast, ${ }^{22}$ probably the most

19 Overviews are provided by Montgomery SLATKIN / Fernando RACIMO, Ancient DNA and Human History, in: Proceedings of the National Academy of Sciences of the United States of America 113 (23) (2016), pp. 6380-6387; Anne GibBons, Revolution in Human Evolution, in: Science Magazine 349, 6246 (2015), pp. 362-366. The development of aDNA-studies has also been thoroughly analysed in a brilliant recent study from the perspective of the history of science, see Elsbeth BösL, Doing Ancient DNA. Zur Wissenschaftsgeschichte der aDNA-Forschung, Bielefeld 2017.

20 But see FEUCHTER (note 18).

21 Sara GOOdACRE / Agnar HeLGASOn / Jane M. NiCHOLSOn / Lorraine SOUTHAM / Lee FERGUSOn / Erin Hickey / Ernesto VEGA / Kári StEFÁnsSon / Ryk WARD / Bryan SyKES, Genetic Evidence for a Familybased Scandinavian Settlement of Shetland and Orkney During the Viking Periods, in: Heredity (Edinburgh) 95(2) (2005), pp. 129-135; Brian McEvoy / Ceiridwen J. EdwARDS, Human Migration: Reappraising the Viking Image, in: Heredity (Edinburgh) 95(2) (2005), pp. 111-112; Georgina R. BowdEn, Excavating Past Population Structures by Surname-based Sampling. The Genetic Legacy of the Vikings in Northwest England, in: Molecular Biology and Evolution 25(2) (2008), pp. 301-309; Brian McEvoy / Claire Brady / Laoise T. MOORE / Daniel G. BRADY, The Scale and Nature of Viking Settlement in Ireland from Y-chromosome Admixture Analysis, in: European Journal of Human Genetics 14(12) (2006), pp. 1288-1294.

22 James F. Wilson / Deborah A. Weiss / Mandy Richards / Mark G. Thomas / Neil N. BRAdman / David K. GolDSTEIN, Genetic Evidence for Different Male and Female Roles During Cultural Transitions in the British Isles, in: Proceedings of the National Academy of Sciences of the United States of America 98(9) (2001), pp. 5078-5083; Michael E. WEALE / Deborah A. WEISS / Rolf F. JAGER / Neil N. BRADMAN / Mark G. Thomas, Y Chromosome Evidence for Anglo-Saxon Mass Migration, in: Molecular Biology and Evolution 19(7) (2002), pp. 1008-1021; Mark G. THOMAS / Michael P. STUMPF / Heinrich HÄRKE, Evidence for an Apartheid-like Social Structure in Early AngloSaxon England, in: Proceedings of the Royal Society, Biological Sciences 273(1601) (2006), pp. 2651-2657; Ana L. TöPf / M. Thomas P. Gilbert / Jack P. DumbacheR / A. Rus Hoelzel, Tracing 
intensively scrutinized migration in Genetic History ${ }^{23}$ to Iceland, Greenland, ${ }^{24}$ or even Newfoundland. ${ }^{25}$ In the second region, the Western Mediterranean, geneticists have been mostly interested in Arabic and Jewish migrations. ${ }^{26}$ In both instances, the majority of studies have sought to quantify the number of people who were 'on the move' and to establish their 'legacy' in the gene pool of today's populations in the regions in question. Genetics is thus trying to answer popular modern questions about identity rooted in history by defining the proportions of a people's ancestry more precisely. Obviously there are many pitfalls to this approach: while the assumption that genetics has anything to do with individual identity is already quite dubious in itself, ${ }^{27}$ its application and the techniques that accompany the entire debate are prone to be abused, be it by public institutions or private groups or individuals. ${ }^{28}$

An example of a very careful and reflective approach that is avoiding the abovementioned pitfalls is a project led by medievalist Patrick GEARY (Institute for Advanced Study, Princeton) on Migrations between Pannonia and Italy at the beginning of the Middle Ages. GEARY and his team are not looking for 'ethnicity' in the aDNA from

the Phylogeography of Human Populations in Britain Based on 4th-11th century mtDNA Genotypes, in: Molecular Biology \& Evolution 23(1) (2006), pp. 152-161; Mark G. THOMAS / Michael P. STUMPF / Heinrich HäRKE, Integration Versus Apartheid in Post-Roman Britain. A Response to Pattison, in: Proceedings of the Royal Society, Biological Sciences 275 (2008), pp. 2419-2421.

23 See treatment in Feuchter (note 18), and SAmida / Feuchter (note 2).

24 Elena Bosch / Francesc Calafell / Zoë H. Rosser / Søren NøRBy / Niels Lynnerup / Matthew E. HuRLES / Mark A. Jobling, High level of Male-biased Scandinavian Admixture in Greenlandic Inuit Shown by Y-Chromosomal Analysis, in: Human Genetics 112(4) (2003), pp. 353-363.

25 Eleanor P. Jones / Heidi M. EAGER / Sofia Isabel GABRIEL / Fríða JóHANNESDótTiR / Jeremy B. SEARLE, Genetic Tracking of Mice and Other Bioproxies to Infer Human History, in: Trends in Genetics 29(5) (2013), pp. 298-308.

26 Maria Jose CASAS / Erika Hagelberg / Rosa Fregel / José María LaRRuga / Ana Maria Gonzalez, Human Mitochondrial DNA Diversity in an Archaeological Site in al-Andalus: Genetic Impact of Migrations from North Africa in Medieval Spain, in: American Journal of Physical Anthropology 131(4) (2006), pp. 539-551; Susan M. ADAMS et al., The Genetic Legacy of Religious Diversity and Intolerance: Paternal Lineages of Christians, Jews, and Muslims in the Iberian Peninsula, in: American Journal of Human Genetics 83(6) (2008), pp. 725-736; Cristian CAPELLI / Valerio ONOFRI / Francesca BRISIGHELLI / Ilaria Boschi / Francesca SCARNICCI / Mara Masullo / Gianmarco FeRRI / Sergio Tofanelli / Adriano TAGLIABRACCI / Leonor Gusmão / António AmoRIM / Francesco GatTo / Mirna KirIN / Davide MerLITTI / María BRión / Alejandro Blanco Verea / Valentino Romano / Francesco CaLì / Vincenzo Lorenzo PASCALI, Moors and Saracens in Europe. Estimating the Medieval North African Male Legacy in Southern Europe, in: European Journal of Human Genetics 17(6) (2009), pp. 848-852.

27 For a more detailed critical discussion see FEUCHTER (note 18).

28 See e. g. Marianne SOMmER, 'Do You Have Celtic, Jewish, Germanic Roots?' - Applied Swiss History Before and After DNA, in: Katharina SCHRAmm / David SkINNER / Richard ROTTENBURG (eds.), Identity Politics and the New Genetics: Re/Creating Categories of Difference and Belonging, Oxford 2012, pp. 116-140, esp. pp. 130-131, and Lorna-Jane RICHARDSON / Tom BоotH, Response to 'Brexit, Archaeology and Heritage: Reflections and Agendas', in: Papers from the Institute of Archaeology 27 (2017), pp. 1-5. 
gravesites they are analysing, but rather for data about demographics, kinship relations, and migratory patterns, with very promising and interesting first results. ${ }^{29}$

\section{Recent Human Evolution}

With the above-mentioned progress in aDNA sampling, considerable improvements have also been made in the study of recent developments and stages in human evolution $^{30}$ : Geneticists are now able to observe evolutionary processes in humans that have taken place not in a distant prehistory, but in historical times, that is in the last few thousand years. ${ }^{31}$ Among the many traits that have been studied by geneticists (including such controversial aspects as body height and skin pigmentation), I want to focus on only one, namely lactose tolerance, i. e. the ability to digest milk and fresh dairy products without experiencing intestinal problems.

Lactose is a sugar that is present in milk and young children are generally able to digest it by cracking it with the help of lactase, an enzyme. The production of this enzyme gets switched off in humans after a certain age. This deactivation of lactase production, however, does not occur in lactose tolerant people: they are thus 'lactase persistent'. Seen on a global level, lactose tolerance is a genetic trait that is not present among most adults in the world, but highly common in some

29 On the project see Patrick J. GEARY, Rethinking Barbarian Invasions Through Genomic History, in: Hungarian Archaeology. Online Journal (Autumn 2014), pp. 1-8, online: http://www.hungarianarch aeology.hu/wp-content/uploads/2014/11/eng_geary_140.pdf (last accessed 15/05/2019); Stefania VAi / Silvio GHIRoTto / Elena PILLI / Francesca TASSI / M. Taheri LARI / Ermanno RizZI / Laura MATASLALueza / Oscar RAmirez / Carles LaluezA-Fox / Alessandro Achilli / Anna Olivieri / Antonio TORRONI / Hovirag LANCIONI / Caterina GIOSTRA / Elena BEDINI / Luisella Pejrani BARICCO / Giuseppe Matullo / Cornelia Di Gaetano / Alberto Piazza / Krishna R. Veeramah / Patrick J. Geary / David CARAmelli / Guido Barbujani, Genealogical Relationships between Early Medieval and Modern Inhabitants of Piedmont, in: PLoS One 10(1) (2015), e0116801; and Carlos Eduardo G. AMORIM / Stefania VAI / Cosimo Posth / Alessandra Modi / István KonCZ / Susanne HAKENBECK / Maria Cristina LA RocCA / Balazs Mende / Dean BoBo / Walter PoHL / Luisella Pejrani BARICCo / Elena Bedini / Paolo FranCALACCI / Caterina Giostra / Tivadar Vida / Daniel Winger / Uta von FreEDEN / Silvia GHIROTTO / Martina LaRi / Guido Barbujani / Johannes Krause / David CARAmelli / Patrick J. GeARY / Krishna R. VEeRAMAH, Understanding 6th-Century Barbarian Social Organization and Migration through Paleogenomics, in: Nature Communications 9(1) (2018), 3547, reviewed by Jörg FeUCHTER, Aber diese Fremden da sind nicht von hier!, in: Frankfurter Allgemeine Zeitung, 12/19/2018.

30 For overviews see Shaohua Fan / Matthew E. B. HAnSEn / Yancy Lo / Sarah A. Tishroff, Going Global by Adapting Local: A Review of Recent Human Adaptation, in: Science 354, 6308 (2016), pp. 54-59; Mark STONEKING, An Introduction to Molecular Anthropology, Hoboken 2017, pp. 321-332.

31 The commonplace definition of 'historical times' is based on the development of writing and thus the production of written records of history - which cover the period of only a few thousand years. There are, however, other views, which are equally justifiable, see, for example, Manfred K. H. EGGERT, Zwischen Paläolithikum und Gegenwart. Überlegungen zum historischen Universum, in: Saeculum 63 (2013), pp. 7-51. 
populations, including most populations living in Europe, and especially in NorthWestern Europe (but there are also populations in certain African regions that are overwhelmingly lactose tolerant). ${ }^{32}$ Since milk and derivative products are an attractive source of protein- and energy-rich nutrition, the capacity to consume them even as an adult certainly provides an important evolutionary advantage. At the same time, it has quite fundamental repercussions on cultural practices as far as the cultivation of particular animal species are concerned.

In view of these important effects, it is hardly surprising that considerable effort is being put into finding out when the decisive genetic mutations (they are not the same everywhere) for lactose tolerance have occurred, when they spread, and how exactly this process is connected to the husbandry of dairy-producing animals (cattle, sheep, goats). ${ }^{33}$ Pertinent research and its results are not only interesting in the context of medical or nutritional issues, where milk is often an important element, but they are of more general interest. In fact, the distribution of lactose tolerance is considered to be a prime example of 'gene-culture-coevolution', ${ }^{34}$ i. e. the mutual interference of cultural habits and genetic traits in a population in a longer-term evolutionary selection process. In other words, while the accidental development of lactose tolerance among adults might have increased the motivation to develop husbandry of specific animals, the latter might also, in turn, have influenced the selective genetic advantage of lactose tolerance.

Currently it can be considered an established scientific fact that lactose tolerance is exclusively acquired via genetic transmission. Recent studies convincingly demonstrate that this trait must have spread among the European populations in the relatively short period of the last 4,000 years. Thus - given it is nowadays so prevalent among people of North-Western Europe - it spread at a staggering pace. ${ }^{35}$ In fact, it might even be the most highly selective genetic trait ever observed among humans. A recent study ${ }^{36}$ has now confirmed - or rather, radicalized - this finding:

32 Annina KRuttli / Abigail S. Bouwman / Guelfirde AKGuel / Philippe Della CaSA / Frank RÜHLI / Christina WARINNER, Ancient DNA Analysis Reveals High Frequency of European Lactase Persistence Allele (T-13910) in Medieval Central Europe, in: PloS One 9(1) (2014), e86251.

33 See e. g. a new research project dedicated to "Cultures of Dairying: Gene-culture-microbiome Evolution and the Ancient Invention of Dairy Foods", funded by the European Research Council, online: http://www.shh.mpg.de/1019083/bos-warinner-erc-starting-grants (last accessed 15/05/ 2019). The principal investigator of this project, which focusses on Mongolia, is Dr. Christina WARINNER, group leader at the Max-Planck-Institute for the Science of Human History.

34 For an outline of the general theory see Linda Stone / Paul F. LURQUin / Luigi Luca CavalLISFORZA, Genes, Culture, and Human Evolution: A Synthesis, Malden / MA 2007.

35 Ian MATHIESON et al., Genome-wide Patterns of Selection in 230 Ancient Eurasians, in: Nature 528 (2015), pp. 499-503.

36 Yair Field / Evan A. Boyle / Natalie Telis / Ziyue Gao / Kyle J. Gaulton / David Golan / Loic Yengo / Ghislain RochelEAu / Philippe Froguel / Mark I. MCCARTHY / Jonathan K. PRITCHARD, Detection of Human Adaptation During the Past 2000 Years, in: Science 354, 6313 (2016), pp. 760-764. 
its authors have come to the conclusion that the entire process of the spread of lactose-tolerance among Europeans occurred in no more than the last 2,000 years. This result puts a particular focus on the Middle Ages. If the geneticists' findings and the assumptions derived from them are accurate, the millennium between 500 and $1500 \mathrm{AD}$ might in fact have been a key period in the spread of lactose tolerance. There is indeed one local study which suggests that the current level of lactose persistence in western central European populations was reached in exactly the period we are interested in. ${ }^{37}$ If we accept this suggestion, we might ask in turn whether families with parents that carried the specific mutation causing lactase persistence in European peoples were at a considerable selective advantage over other families during the Middle Ages? In order to study this question in sufficient depth, we must not only retrieve and analyse aDNA from medieval individuals, all related data from historical sources concerning dairy production, cattle husbandry, consumption of milk, cheese and other dairy produce is also highly relevant. ${ }^{38}$ Medieval historians obviously would have much to contribute from their traditional sources, the texts, but obviously also from images that show animals, farming conditions, and practices, etc. Finally, there is even a type of source where both kinds of information - DNA and textual - combine, which will be treated below.

\section{Parchment Studies}

Parchment was, by and large, the most important writing material for most of the European Middle Ages. Papyrus played only a very minor role (and mostly only at the beginning of the era), while paper was only introduced in the course of the last centuries of Middle Ages, even though it quickly replaced parchment in many fields. ${ }^{39}$ Wax tablets, another medium for text, were usually only employed for nonpermanent writing, although there are some exceptions.

But how does this widely used writing medium come to be of value when exploring the relationship between genetics and history? First of all, parchment is made from animal skin (cattle, sheep, or goat) and the idea of extracting DNA from it has been around for some years. ${ }^{40}$ Yet only recently have very promising technological

37 KRUTTLI et al. (note 32).

38 See ibid., Abstract: "A history of dairying is presumed to be a prerequisite."

39 See Carla MeYer / Sandra Schulz / Bernd SCHNeidMülLER (eds.), Papier im mittelalterlichen Europa. Herstellung und Gebrauch (Materiale Textkulturen 7), Berlin 2015.

40 Cf. Timothy L. STINSON, Knowledge of the Flesh. Using DNA Analysis to Unlock Bibliographical Secrets of Medieval Parchment, in: Papers. Bibliographical Society of America 103(4) (2009), pp. 435-453. See also the overview in Matthew D. Teasdale / Nienke L. van Doorn / Sarah Fiddyment / Christopher C. WeBb / Terry O’Connor / Michael Hofreiter / Matthew J. Collins / Daniel G. BRAdLEy, Paging Through History. Parchment as a Reservoir of Ancient DNA for Next 
advances been made: most importantly, the problem of contamination by DNA from other individual animals or by human DNA - be it in the process of preparation of the parchment or afterwards - has been solved by using a modern sequencing technique called 'Next Generation Sequencing'. This technique, which has replaced the earlier Polymerase Chain Reaction method, finally made it possible to retrieve mitochondrial $^{41}$ aDNA from seventeenth- and eighteenth-century sheep-skin parchment, to fully sequence it, and to attribute this material to specific breeds. ${ }^{42}$ The technological development thus opens up spectacular possibilities, since, as has already been indicated, medieval parchment combines two kinds of information: not only does it contain the DNA geneticists are looking for as their primary material, but in many cases the material object includes a precise date. Such dates appear, for example, as part of the text of charters. In these cases, the objects provide us with "a [chronological] level of resolution not readily achievable with any other historic DNA source." 43 Moreover, charters usually also mention the name of the place where the document was created and although there are inaccuracies in some cases, such indications are generally correct. If we are right in assuming that skins did not travel long distances and were not kept in stock for long periods before being used (at least not in general), this particular combination of information makes chronological and spatial attribution of the animal that was used for the production of the parchment possible and even very easy. There is thus no need for expensive and much less exact methods like radiocarbon dating or isotope analysis, which are usually employed to ascertain the date and region of origin of medieval artefacts. This makes parchment an ideal resource for serial information about medieval animals, their husbandry and breeding. ${ }^{44}$

\section{Conclusion}

The relevance of the medieval for genetics can be demonstrated in several contexts: medieval pandemics constitute a source of important data for today's medical

Generation Sequencing, in: Philosophical transactions of the Royal Society of London. Series B, Biological sciences 370, 1660 (2015), 20130379, p. 2.

41 Mitochondrial DNA is different from nuclear DNA. It is contained not in the nucleus of the cell, but in the mitochondria (the cell's energy reservoirs). Mitochondrial DNA is transmitted only through females.

42 TEASDAlE et al. (note 40).

43 Ibid.; as the authors remark, even undated writing on parchment can easily be narrowed down to a century by palaeographic evidence.

44 See also a new study by the same laboratory, which managed to glean even more biological information from much older parchment material: Matthew D. TEASDALE / Sarah FidDYMENT / Jiri VNOUCEK / Valeria Mattiangeli / Camilla Speller / Annelise Binois / Martin Carver / Catherine Dand / Timothy P. NEWField / Christopher C. WebB / Daniel G. BRAdLEy / Matthew J. Coldins, The York Gospels: a 1000year biological palimpsest, in: Royal Society Open Science 4(10) (2017), 170988. 
research; medieval migrations are both showcases and test cases for the tools of population genetics and the medieval millennium (500-1500 AD) might well become an essential period for studies in recent human evolution. Even such much-studied medieval objects as parchments have the potential to reveal a whole field of previously hidden data by providing polyvalent source material. Thus, the relevance of the medieval for genetics cannot seriously be doubted here.

Yet there is another problem, which lies elsewhere, and which some might consider to be the real question: are medievalists still relevant? Will they and their skills still be needed and sought for, once the medieval becomes the serious focus of geneticists? If we consider the minuscule number of medieval historians who figure among the authors of studies in the field(s) where genetics and Medieval Studies intertwine - or who are at least noticed and quoted - one might seriously doubt that medievalists are really prepared for this future. ${ }^{45}$

But even if things progress and historians finally decide to participate in a common endeavour and engage in this field of research and its debates, several caveats should be kept in mind. First and foremost amongst them, it seems important that historians do not accept to become mere contributors of data, but that they seek to be involved actively in the fundamentals of the research design process: currently, the way many geneticists work with history has been aptly described by Mark JoBling, himself a geneticist, as "cherry-picking" those facts from history that fit the hypothesis built from the DNA findings, while other facts are left out! ${ }^{46}$ Historians should certainly not be content with being better suppliers of cherries; nor should they take the geneticists' results at face value just because they are the products of quantifiable science. In order to be able to cooperate in a fertile way, that is conceptually, with geneticists - but also in the spirit of mutual correction through insight into each other's disciplinary limitations - historians should inform themselves thoroughly about genetics' methods both in general, but also in particular when they are applied to medieval objects and questions of medieval history. Not every historian needs to do this, of course, but more should do so than is currently the case. ${ }^{47}$

45 On this see FeUCHTER (note 18), and SAMIDA / FEUCHTER (note 2).

46 Mark A. Jobling, The Impact of Recent Events on Human Genetic Diversity, in: Philosophical Transactions of the Royal Society of London. Series B, Biological sciences 367, 1590 (2012), pp. 793-799, here p. 794: "An additional problem is that geneticists who observe a pattern in their data and seek an explanation for it tend to visit a library, take out a history book and read about a past event that seems to explain the pattern they see. This kind of historical cherry-picking leads to a lack of objectivity in asking what kinds of past events could have given rise to modern genetic diversity."

47 Bibliographical note: After the present text has been edited, the following emerging field essay was published: Elsbeth BöSL / Jörg FEUCHTER, Genetic History - eine Herausforderung für die Geschichtswissenschaften, in: Neue Politische Literatur 64(2) (2019), pp. 237-268. 
